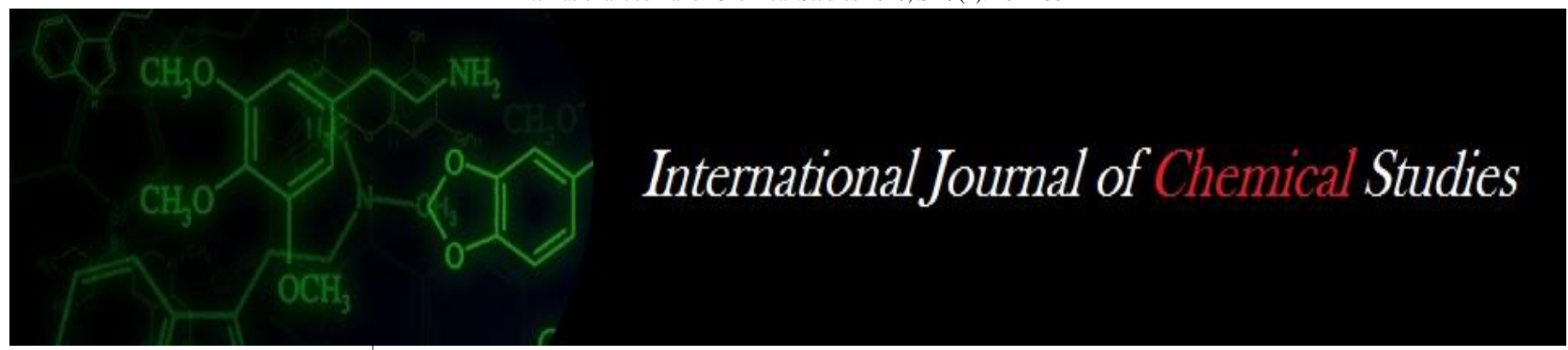

P-ISSN: 2349-8528

E-ISSN: 2321-4902

www.chemijournal.com

IJCS 2021; SP-9(1): 102-106

(C) 2021 IJCS

Received: 15-11-2020

Accepted: 26-12-2020

SKS Rajpoot

Crop Research Station,

ANDUAT, Ghaghraghat,

Bahraich, Uttar Pradesh, India

\section{Evaluation of frontline demonstration of sesame (Sesamum indicum L.) for sustainable food production in Sonbhadra district of Uttar Pradesh}

\author{
SKS Rajpoot
}

DOI: https://doi.org/10.22271/chemi.2021.v9.i1b.11450

\title{
Abstract
}

Sesame (Sesamum indicum L.) is one of the important oilseed crops in Indian agriculture. One of the major constraints traditional sesame farming is low productivity of local Uarieiies. The Krishi Vigyan Kendra, Sonbhadra Eastern Uttar Pradesh has conducted frontline demonstration at adopted farmer's field during kharif 2015-16 and 2016-17 with variety of sesame JTS 08 and RT 346. Front line demonstration were conducted at 40 farmers field, to demonstrate production potential and economic benefit of improved technologies comprising short duration, phyllody resistant varieties, line sowing, integrated nutrient management and timely weed management, integrated nutrient, pest and disease management. The improved technology recorded a mean yield of $8.07 \mathrm{q} / \mathrm{ha}$ which was $62.1 \%$ higher than that obtained with farmers practice yield of $5.14 \mathrm{q} / \mathrm{ha}$. The improved technologies resulted higher mean net income of Rs.39115/ha with a benefit cost ratio of 4.74 as compared to local practice (Rs.24905/ha, 3.61 respectively). Sonbhadra conditions and this will accelerate the adoption of newer varieties to increase the productivity of sesame in this area. There is a need to adopt multi-pronged strategy that involves enhancing sesame production through area expansion and productivity improvements through better adoption of improved technology.

Keywords: Frontline demonstration, technology gap, extension gap, and technology index

\section{Introduction}

India is one of the major producers of many oilseed crops like groundnut, mustard, rapeseed, sesame seed, etc. Traditionally, Indians consume substantial quantity of edible oils mainly as a cooking medium. Among the oilseed crops, sesame has been cultivated for centuries, particularly in Asia and Africa, for its high content of edible oil and protein. It is commonly known as til (Hindi), hu ma (Chinese), sesame (French), goma (Japanese), gergelim (Portuguese) and ajonjoli (Spanish). Sesame (Sesamum indicum L.) is pioneer among the domesticated oilseed crops being still cultivated throughout the world in about 70 countries, out of which 26 are located in Africa and 24 in Asia. It is grown worldwide over an area of 75 million hectares producing 60,000 t seed (FAOSTAT 2008). Myanmar, Sudan, China and India are the leading sesame-producing countries of the world. The crop is generally adapted to tropical regions of world, where it is mainly grown for edible seeds and oil (Weiss 2000) ${ }^{[1]}$. Despite its ideal adaptation to dry climates, sesame can also be grown in humid, tropical and subtropical regions. Traditionally, it is cultivated between latitudes 6 and $10{ }^{\circ} \mathrm{N}$ (Agboola 1979) ${ }^{[1]}$ with the highest yield-producing countries in Asia and Africa (FAOSTAT 2008). Sesamum orientale and Sesamum indicum are the alternatively used scientific names of sesame (Bedigian 2003) ${ }^{[2]}$. However, Nicolson and (Wieserma 2004) proposed S. indicum name against $\mathrm{S}$. orientale, which was conserved against $\mathrm{S}$. orientale and is in use since 2005. Sesame seeds are rich in oil and protein with high dietary energy value of $6,355 \mathrm{kcal} \mathrm{kg}-1$. Chemical composition of seed shows that it contains $57-63 \%$ oil, 23-25\% protein, $13.5 \%$ carbohydrate and 5\% ash (Tunde-Akintunde and Akintunde 2004; Elleuch et al. 2007) ${ }^{[5,12]}$. It is rich source of various nutritional elements including iron, magnesium, manganese, copper and calcium, and important vitamins B1 (thiamine) and E (tocopherol). Due to its flavor and stability as well as high-quality cooking value, sesame fat is of great significance in the food industry. The presence of sesamin and sesaminol lignans in its non-glycerol fraction contributed to oxidative stability and antioxidative activity of sesame oil (Wu 2007) ${ }^{[5]}$. 
These antioxidative agents terminate the process of oxidative damage in cells by capturing oxidative radicals. Antioxidants are also used as dietary supplements to cure cancer and heart diseases. The most abundant fatty acids present in sesame oil include: oleic acid (43\%), linoleic acid $(35 \%)$, palmitic acid $(11 \%)$ and stearic acid $(7 \%)$ contributing toward $96 \%$ of total fatty acids (Elleuch et al. 2007) ${ }^{[5]}$. The crop is now grown in a wide range of environments, extending from semi-arid tropics and subtropics to temperate regions. Consequently, the crop has a large diversity in cultivars and cultural systems. India is the largest producer of sesame in the world. In general, average productivity of sesame continues to be lower (144 to $234 \mathrm{~kg} / \mathrm{ha}$ ) than expected from agricultural technology for the last 20 years, mainly due to its cultivation on marginal lands, under poor management and without inputs except seed. The major constraint responsible for lower yield is inappropriate production technologies viz; broadcast method of sowing, no use of fertilizer and untimely weed management (45 DAS), (Khaleque and Begum, 1991) ${ }^{[8]}$. In the medium term, accelerating import substitution, improving efficiency of the oil processing sector, and judicious use of tariffs are vital (Chand et al., 2004) [3, 10]. The improved technology packages were also found to be financially attractive. Yet, adoption levels for several components (of the improved technology were low, emphasizing the need for better dissemination (Kiresur et al., 2001) ${ }^{[9]}$.

Several biotic, abiotic, and socioeconomic constraints inhibit exploitation of the yield potential and these needs to be addressed. Sonbhadra and its population wholly dependent on agriculture and allied activities. With the start of technology mission on oilseeds, frontline demonstration on sesame using new crop production technology was started with the objectives of showing the productive potentials of the new production technologies under real farm situation over the locally cultivated sesame crop. Keeping this in view, frontline demonstrations on sesame were conducted to demonstrate the production potential and economic benefits of latest improved technologies on farmer's fields.

\section{Materials and Methods}

Frontline Demonstration is the new concept of field demonstration evolved by ICAR with the inception of technology mission on oilseeds and pulses. The main objective of frontline demonstrations is to demonstrate newly released crop production technologies and its management,practices in the farmer's field. The present study was carried out by the Krishi Vigyan Kendra, Sonbhadra Achrya Narendra Deva University of Agriculture \& Technology, Ayodhya (U.P.), four consecutive years in the farmer's field in two block Ghorawal and Robertsganj of 10 adopted villages viz., Silhata, Pagia, Bari, Obradeeh, Banjaria, Pithori, Gourahi, Ailahi,Papi, Ghuwani and Manapur of Sonbhadra district. The soil was red, black with shallow depth and rocky nature located in undulated terrain is another problem of the district. The land preparation, choose the tillage practices that will ensure to keep the soil in its best physical condition for a favorable crop's growth and development. Plow and harrow the soil to a depth which will physically support the plant and allow the use of sufficient moisture and nutrients; sufficient enough to control weeds; and must leave the soil surface level. A level field improves water use efficiency, helps control in crop weeds and allows the rapid removal of excess water. Level the soil by plowing and harrowing. Soil treatments of FLDs Demonstration fields were taken by using trichoderma @ $5 \mathrm{~kg} / \mathrm{ha}$ and plant protection measures adopted during crop. Make the furrows at desired depth and distance during the last plowing. Distance in between furrows was $75 \mathrm{~cm}$ x $75 \mathrm{~cm} ; 90 \mathrm{~cm}$ x $90 \mathrm{~cm} ; 100$ $\mathrm{cm} \times 100 \mathrm{~cm}$, thinning of the plants attain height of $10-15 \mathrm{~cm}$, remove the weak and diseased plants. It is important to achieve 22plants/meter in order to attain a high yield. FLD on Sesame (Til) were cultivated during Kharif season and sown first fortnight of July. Sesame (Til) crop was sown in line and fertilize with a common dose of N: P: K: S @ 60:40:40:25 kg/ ha. 1/2 dose of Nitrogen, Full dose of Phosphorus, Potash and Sulphur applied at sowing time. 1/2 dose Nitrogen after first irrigation or after showering near about 15 to $25 \mathrm{DAS}$ at the time earthing-up/thinning. Seed treatment done by using carbendazim @ $2 \mathrm{~g} / \mathrm{kg}$ seed 2 to 3 days before sowing. The weeds are easier to control on their earlier growing period. Spraying of pendamathlin@ 3.5 1/ha after two or three days after sowing. Materials and methods adopted for front line demonstration are given in table 1. The FLD was conducted to study the gaps between the potential 'yield and demonstration yield, extension gap and the technology index. The Krishi Vigyan Kendra of Sonbhadra conducted frontline demonstrations 36 were organized on farmer's field to demonstrate the impact of crop management technology on sesame productivity over three years during Kharif season 2014-15to 2016-17. Each frontline demonstration was laid out on 0.4 ha area, adjacent 0.4 ha was considered as control (farmer's practice). The improved technologies package included field pea wilt resistant varieties, line sowing, integrated nutrient management and timely weed removal. The variety of sesame JTS 08 (2015-16) and RT 346 (201617 ), on date of sowing 25 July $-31^{\text {st }}$ July in all years. Most of the participating farmers kept a control plot from comparison. The cropping period was split into different growth period. All the farmers were imparted field training on the particular operation of the field pea cultivation. The participating farmers were provided with all advance technical know how about advanced cultivation of Sesame crop. KVK scientist also visited regularly to the demonstrations fields and continuously guides the farmers. Field days and group meeting were also organized at demonstration sites to provide the opportunities for other farmers to witness the benefits of demonstrated technologies.

\section{Insect pests and control Aphids and leaf hoppers}

Indicate the total number found (top two leaves, middle two leaves and bottom one leaves) and the total number of leaves checked (20 plants calculate the average per leaf).

\section{Leaf webber or roller and capsule borer larvae}

Indicate the total number of fruiting parts checked. Indicate the total number of pods with pod borer damage.

\section{IPM}

Pheromone traps for Antigastra, Acherontia, Spilosoma and Amsacta@ @-5/acre have to be installed. Install the traps for each species separated by a distance of $>75$ feet in the vicinity of the selected field. Fix the traps to the supporting pole at a height of one foot above the plant canopy. Change of lures should be made at 2-3 week interval (regular interval). During each week of surveillance, the number of moths/trap/week should be counted and recorded year round. The trapped moths should be removed and destroyed after each recording. 


\section{Botanical pesticides}

Grind $50 \mathrm{~g}$ of ginger and make into paste. Mix with 3 liters of water. Strain. Add $12 \mathrm{ml}$ of soap. Mix well. Ten (10) $\mathrm{kg}$ of ginger is needed for 1 ha.

\section{Spray solutions}

Ammonia spray Mix 1 part ammonia with 7 parts water. This spray also controls flea beetles. Soap spray Mix $2 \frac{1}{2}$ tablespoons of liquid soap to a galloon of water.

Most sesame seeds are processed directly into oil by the grower or within the producing region but are also sold in various stages of processing, for various uses, such as meal, paste, confections and bakery products (Salunkhe et al., 1991). Sesame harvested, the seeds are cleaned and dried to about $8 \%$ moisture and then stored before crushing. The primary data was collected from the selected FLD Farmers by random crop cutting method while personal interview schedule for technology performance and acceptance. Before harvesting final plant height $(\mathrm{cm})$ was recorded. The crop was harvested at maturity stage. From front line demonstration plots and farmers practice plot (control plot) and finally extension gap, technology gap, and technology index were calculated as given as formula suggested by (Samui et al. 2000 and Dayanand et al. 2012) ${ }^{[4,11]}$ as given below.

1. $\%$ increase over farmers practices $=$ Improved practices Farmers practices / farmers practices x 100

2. Technology gap $=$ Potential yield - Demonstration yield

3. Extension gap $=$ Demonstration yield - farmers yield

4. Technology index $=[($ Potential yield - Demonstration yield)/Potential yield ] x 100

\section{Results and Discussion}

During the 2015-16 and 2016-17 of two years study period it was observed that the adoption of improved production technologies in demonstration trials has increased the yield over the farmers' practices. Frontline demonstration was conducted on 10 hectares of land with 40 demonstration plots involving JTS 08 \& RT 346 sesame variety. The growth and yield attributing parameters are increased with improved production technology. On an average of three years study, the plant height, Number of capsules per plant and Number of seeds/capsules and test weight increase were observed 133 $\mathrm{cm}, 90.7,80.2$ and $2.94 \mathrm{~g}$, respectively compare to farmers practice (114 cm, 65.8, 61.3 and $2.03 \mathrm{~g}$, respectively) presented in table $2 \&$ figure 1 . The result indicates that the Front line demonstration has given a good impact over the farming community of Sonbhadra as they were motivated by the new agricultural technologies applied in the FLD plots (Chand, 2002) ${ }^{[3,10]}$. Yield of sesame was varied in different years, which might be due to the soil moisture availability \& rainfall condition, climatic aberrations, disease and pest attacks as well as the change in the location of trials every year. The high yielding variety had performed extremely well when compared to local check. The percentage increase in the yield over local check was $62.1 \%$ over farmers practice. The technology gap which shows the gap in the demonstration yield over potential yield was 2.35 to 1.52 during 2015-16 and 2016-17, respectively presented in table $3 \&$ figure 2 . The additional cost increased in the improved technologies was mainly due to more cost involved in balanced fertilizer, improved seed and weed management practices. Similar results also have been reported by (Khan et al. 2009). To get maximum yield of sesame recommended package of practices should be followed. By not following any one management practice yield may be reduced severely and it was also observed that delay in sowing, unbalanced does of fertilizer, untimely weed management and plant protection drastically reduced the grain yield of sesame.

The technology gap observed may be attributed to dissimilarity in the soil fertility status and weather conditions. Hence location specific recommendation appears to be necessary to bridge the gap between the yields. The highest extension gap of 3.55 was recorded during 2015-16 which emphasized the need to educate the farmers through various means for the adoption of improved high yielding varieties and newly improved agricultural technologies to reverse this trend of wide extension gap. More and more use of new HYV's by the farmers will subsequently change this alarming trend of galloping extension gap (Hedge, 2004) ${ }^{[7,9]}$. This high extension gap in all these varieties requires urgent attention from planners, scientists, extension personnel and development departments. The lower the value of technology index more is the feasibility of the technology, the new technologies. Will eventually lead to the farmers to discontinuance of old varieties with the new technology, the technology index shows the feasibility of the evolved technology at the farmers' field. The technology index is 23.50 and 15.20 percent during two years study, respectively which shows the good performance of ICM in Sonebhadra conditions and this will accelerate the adoption of. Newer technologies to increase the productivity of sesame in this area. These results are in conformity with the findings of (Sagar and Ganesh Chandra 2004) ${ }^{[10]}$.

The economic viability of improved demonstrated technology over farmers practice was calculated depending on prevailing price of inputs and outputs cost and represented in the term of $\mathrm{B}: \mathrm{C}$ ratio (table $4 \&$ figure 3 ). It was found that the cost of production of sesame under demonstration with an average Rs. 8245 under control. The additional cost increased in demonstration was mainly due to more cost involved in balanced fertilizer, procurement of improved seed and ICM practices. The cultivation of sesame under improved technologies gave average net return of Rs. 39115/ha which was lower Rs. 24905 in farmer's practices. The benefit cost ratio of sesame with an average of 4.74 in demonstration plots and 3.61 farmers practice. This may be due to higher yield obtained and lower cost of cultivation under improved technologies compared to farmers practice.

There is a need to adopt multipronged strategy which involves enhancing sesame production through horizontal and vertical expansion and productivity improvements through better adoption of improved technology.

Table 1: Improved production technology and farmers practices of sesame under FLD

\begin{tabular}{|c|c|c|c|c|}
\hline Sl. No. & Technology & Improved practices & Farmers practice & GAP (\%) \\
\hline 1 & Variety & JTS 08 \& RT 346 & Old variety & 100 \\
\hline 2 & Time of sowing & July & July & No. gap \\
\hline 3 & Treatment of seed & carbendazim @ $2 \mathrm{~g} / \mathrm{kg}$ seed 2 to 3 days before sowing & No. treatment & 100 \\
\hline 4 & Pre-emergent herbicide & Pendimethalin (@ 3 1/ha) & & \\
\hline 5 & Seed rate & $12-15 \mathrm{~kg} / \mathrm{ha}$. & $18-20 \mathrm{~kg} / \mathrm{ha}$ & Partial gap \\
\hline 6 & Sowing method & Line Sowing & Brodcosting & 100 \\
\hline
\end{tabular}




\begin{tabular}{|c|c|c|c|c|}
\hline 7 & Fertilizer dose (NPKS kg/ha) & $60: 40: 40: 25 \mathrm{~kg} / \mathrm{ha}$ & $60 \mathrm{~kg} / \mathrm{ha}$ only N & Partial gap \\
\hline \multirow{4}{*}{8} & & $\begin{array}{c}\text { Pheromone traps 4-5/acre,50 g of ginger and make } \\
\text { into paste. Mix with 3 liters of water. Strain. Add 12 } \\
\text { ml of soap, Ammonia spray Mix 1 part ammonia with } \\
7 \text { parts water,Soap spray Mix 21/2 tablespoons of liquid } \\
\text { soap to a galloon of water }\end{array}$ & $\begin{array}{c}\text { Non-adoption of recommended } \\
\text { package of practices and injudicious } \\
\text { use of pesticides and spray Dursban } \\
\text { 20 EC (Chloropyriphos) @ } \\
500 \mathrm{ml} / \mathrm{acre}\end{array}$ \\
\hline
\end{tabular}

Table 2: Growth and yield attributing characters of sesame through FLDs

\begin{tabular}{|c|c|c|c|c|c|c|c|c|c|c|}
\hline \multirow[b]{2}{*}{ Year } & \multirow[b]{2}{*}{ No. of demo } & \multirow[b]{2}{*}{ Area $(\mathrm{Ha})$} & \multicolumn{2}{|c|}{ Plant height (cm) } & \multicolumn{2}{|c|}{ No. of capsules/plant } & \multicolumn{2}{|c|}{ No. of seeds/capsule } & \multicolumn{2}{|c|}{1000 seed weight } \\
\hline & & & Demo & FP & Demo & FP & Demo & FP & Demo & FP \\
\hline $2015-15$ & 15 & 5 & 129 & 115 & 87.8 & 60.6 & 74.6 & 66.8 & 2.93 & 2.11 \\
\hline $2015-16$ & 17 & 7 & 131 & 119 & 89.6 & 68.2 & 78.7 & 62.4 & 3.01 & 1.93 \\
\hline 2016-17 & 18 & 6 & 135 & 109 & 91.8 & 63.4 & 81.6 & 60.2 & 2.87 & 2.12 \\
\hline Average & 17 & 6 & 132 & 114 & 89.7 & 64.1 & 78.3 & 63.1 & 2.94 & 2.05 \\
\hline Total & 50 & 18 & - & - & - & - & - & - & - & - \\
\hline
\end{tabular}

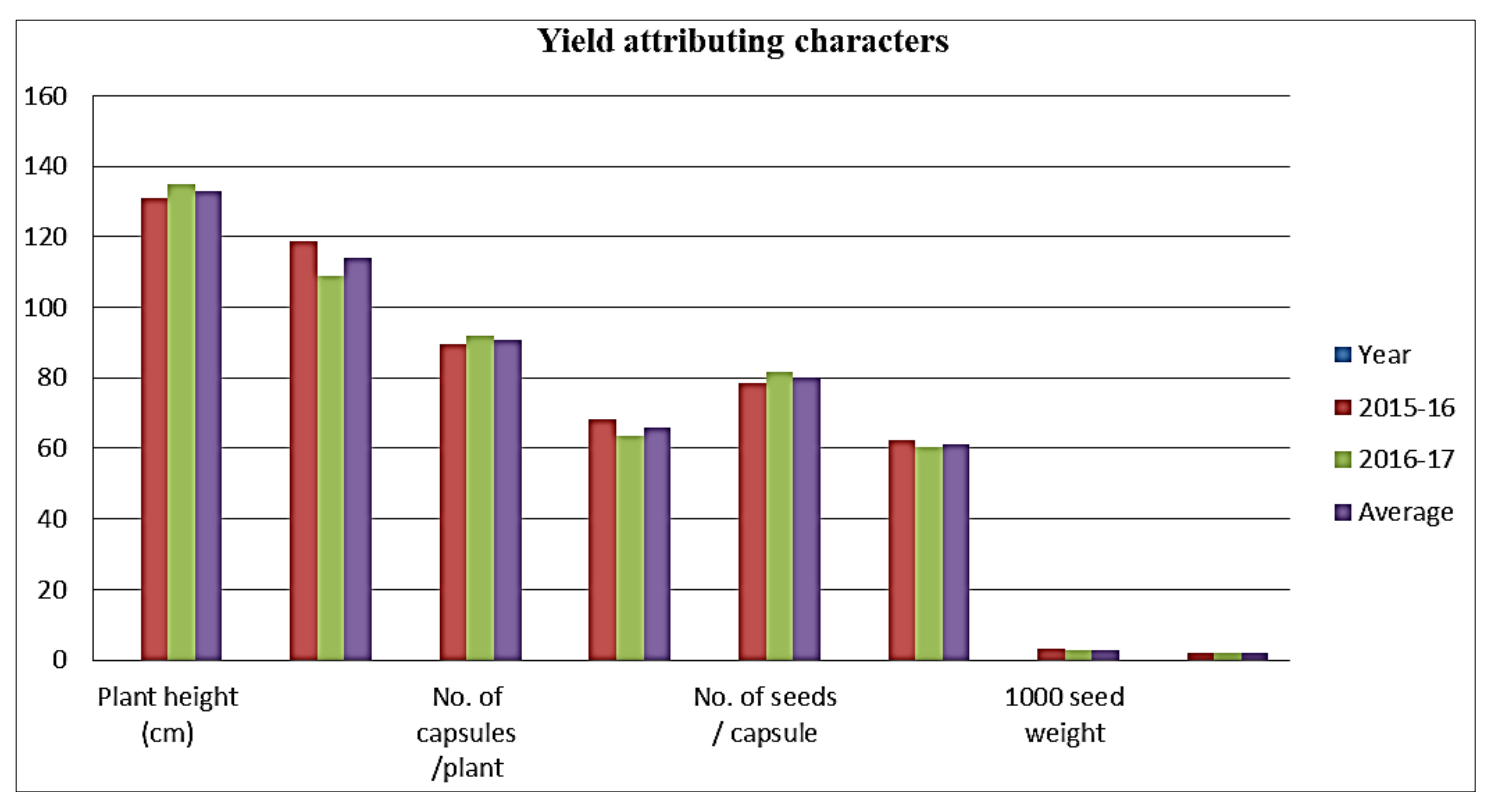

Fig 1: Plant growth and yield attributing characters

Table 3: Performance of front line demonstrations (FLD) of sesame

\begin{tabular}{|c|c|c|c|c|c|c|c|c|c|}
\hline \multirow{2}{*}{ Year } & \multirow{2}{*}{$\begin{array}{c}\text { No. of } \\
\text { demo }\end{array}$} & \multirow{2}{*}{ Area (Ha) } & $\begin{array}{c}\text { Potential grain } \\
\text { yield (q/ha) }\end{array}$ & \multicolumn{2}{|c|}{ Grain yield (q/ha) } & \% increase over & $\begin{array}{c}\text { Extension gap } \\
\text { (q/ha) }\end{array}$ & $\begin{array}{c}\text { Technology gap } \\
(\mathbf{q} / \mathbf{h a})\end{array}$ & $\begin{array}{c}\text { Technology } \\
\text { index }\end{array}$ \\
\hline $2015-16$ & 20 & 5 & 10 & 7.65 & 4.10 & 86.58 & 3.55 & 2.35 & 23.50 \\
\hline $2016-17$ & 20 & 5 & 10 & 8.48 & 6.17 & 37.43 & 2.31 & 1.52 & 15.20 \\
\hline Average & 20 & 5 & 10 & 8.07 & 5.14 & 62.01 & 2.93 & 1.94 & 19.35 \\
\hline
\end{tabular}

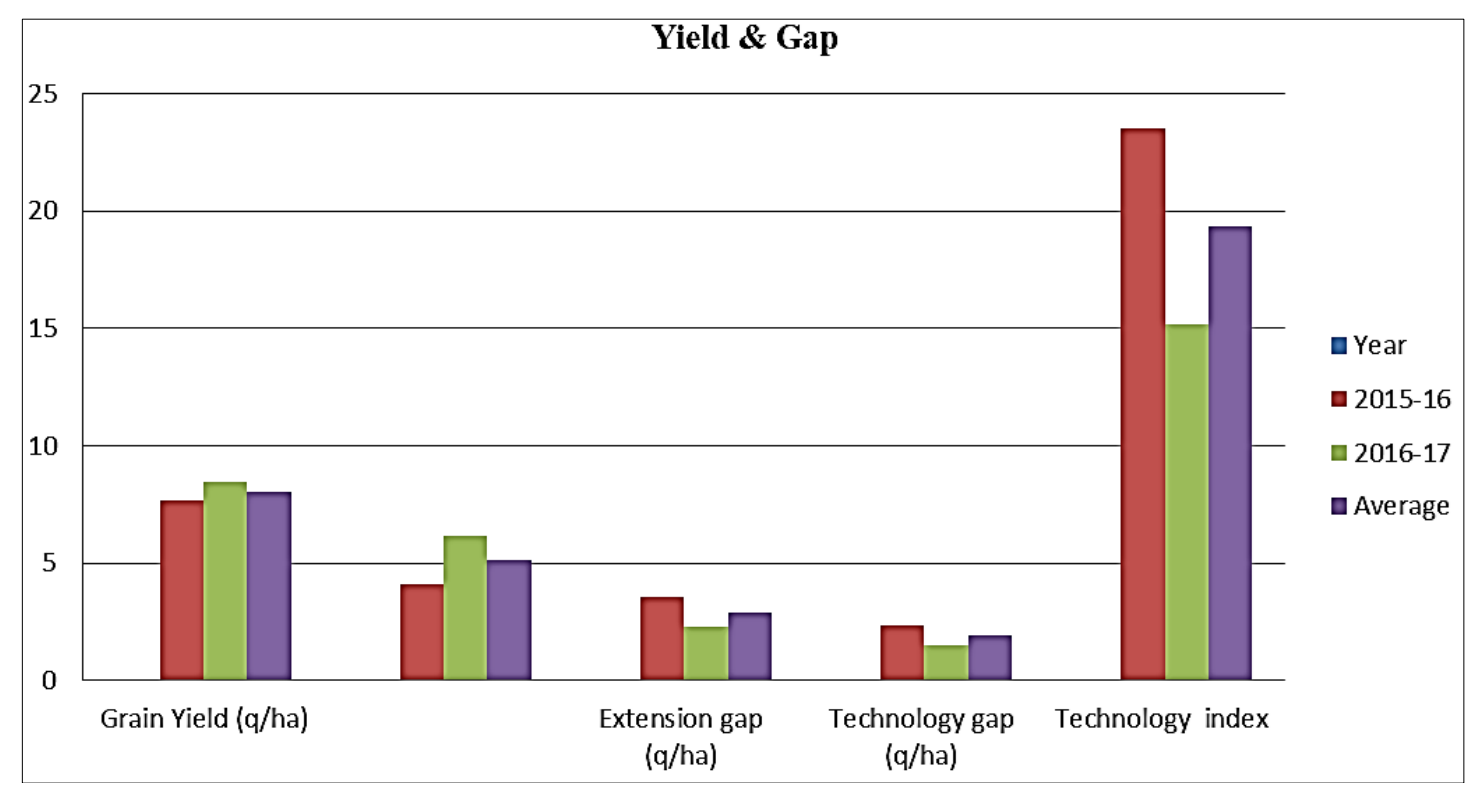

Fig 2: Grain yield and gap of FLD 
Table 3: Seed yield and economics of sesame as affected by improved and local practices in farmers' fields

\begin{tabular}{|c|c|c|c|c|c|c|c|c|c|c|c|c|c|}
\hline \multirow[t]{2}{*}{ Year } & \multirow[t]{2}{*}{\begin{tabular}{|c|}
$\begin{array}{c}\text { Potential } \\
\text { grain yield } \\
(\mathbf{q} / \mathbf{h a})\end{array}$ \\
\end{tabular}} & \multicolumn{2}{|c|}{$\begin{array}{c}\text { Cost of } \\
\text { cash input }\end{array}$} & \multirow[t]{2}{*}{\begin{tabular}{|c|}
$\begin{array}{c}\text { Additional cost in } \\
\text { demonstrations } \\
\text { (Rs./ha) }\end{array}$ \\
\end{tabular}} & \multirow[t]{2}{*}{$\begin{array}{l}\text { Sale price of } \\
\text { grain (MSP) } \\
(\mathrm{Rs} . / \mathrm{qt})\end{array}$} & \multicolumn{2}{|c|}{$\begin{array}{l}\text { Grain yield } \\
\text { (q/ha) }\end{array}$} & \multirow[t]{2}{*}{$\begin{array}{c}\text { \% increase in } \\
\text { yield over } \\
\text { farmers practice }\end{array}$} & \multicolumn{2}{|c|}{$\begin{array}{l}\text { Total returns } \\
\text { Rs. (ha }\end{array}$} & \multirow{2}{*}{$\begin{array}{c}\text { Extra } \\
\text { returns }\end{array}$} & \multicolumn{2}{|c|}{$\begin{array}{c}\text { Incremental } \\
\text { benefit: Cost ratio }\end{array}$} \\
\hline & & Demo & FP & & & Demo & FP & & \begin{tabular}{|l|} 
Demo \\
\end{tabular} & FP & & Demo & FP \\
\hline $2015-16$ & 10 & 7890 & 6650 & 1240 & 4700 & 7.65 & 4.10 & 86.58 & 35955 & \begin{tabular}{|l|}
19270 \\
\end{tabular} & 28065 & 4.56 & 2.90 \\
\hline 2016-17 & 10 & 8600 & 7160 & 1440 & 5000 & 8.48 & 6.17 & 37.43 & 42400 & 30850 & 33800 & 4.93 & 4.31 \\
\hline Average & 10 & 8245 & 6905 & 1340 & 4850 & 8.07 & 5.14 & 62.01 & 39115 & 24905 & 30870 & 4.74 & 3.61 \\
\hline
\end{tabular}

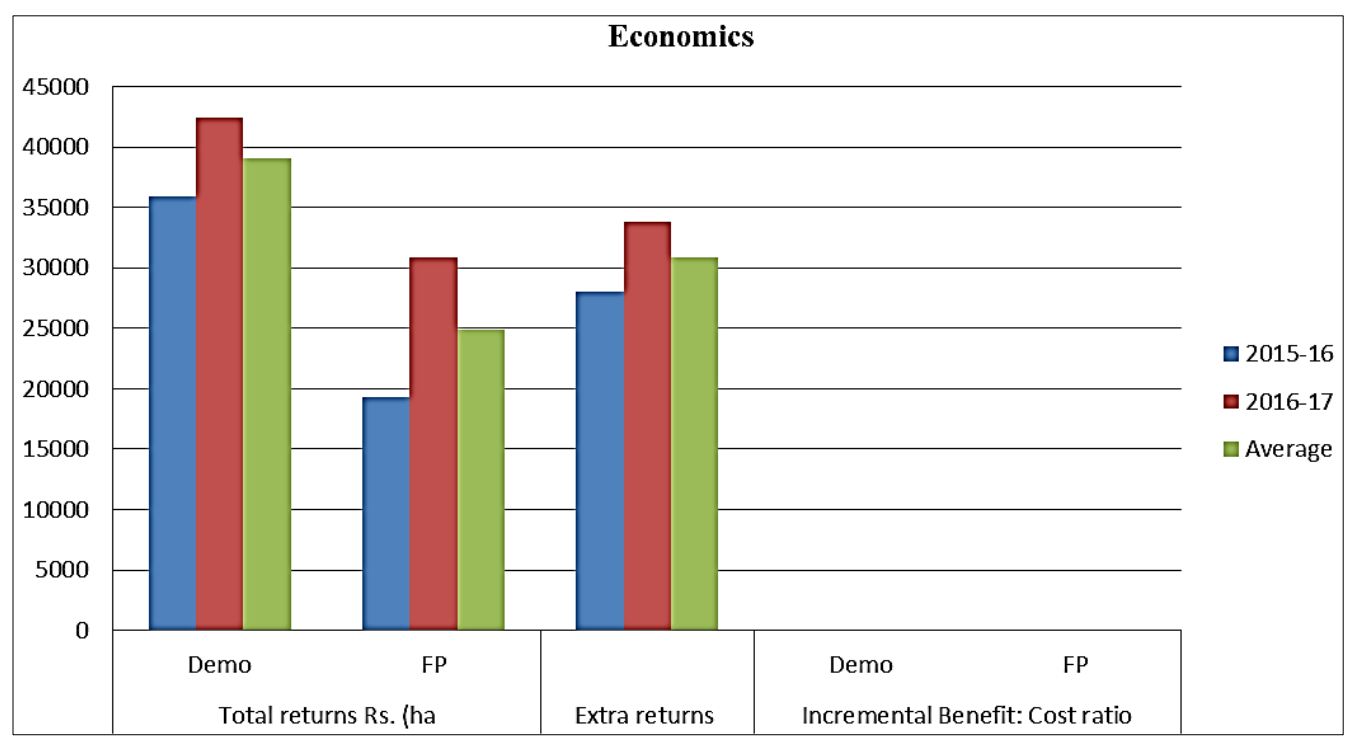

Fig 3: Economics of FLD sesame

\section{Conclusion}

In the fragile environments and poor farm resource base, sesame is the best choice for farmers. Cultivation of sesame also helps in protecting the environment from the risk of high input agriculture.

\section{References}

1. Agboola SA. The agricultural atlas of Nigeria. Oxford University Press, Oxford. Weiss EA (2000) Oilseed crops, 2nd edn. Oxford, Blackwell Science 1979, P131164.

2. Bedigian D. Sesame in Africa: origin and dispersals. In: Neumann K, Butler A, Kahlheber S (eds) Food, Fuel and Fields - Progress in African Archaeobotany, Africa Praehistorica. Heinrich-Barth-Institute, Cologne 2003, P17-36.

3. Chand Ramesh. Trade Liberalization, WTO an Indian Agriculture. Chapter 4, Mittal Publ, New Delhi 2002.

4. Dayanand VRK, Mehta SM. Boosting mustard production through front line demonstrations. Indian Res J Ext Edu 2012;12(3):121-123.

5. Elleuch M, Besbes S, Roiseux O, Blecker C, Attia H. Quality characteristics of sesame seeds and by-products. Food Chem 103:641-650. Wu WH The contents of lignans in commercial sesame oils of Taiwan and their changes during heating. Food Chem 2007;104:34-344.

6. FAO Statistics Division 2008. http://faostat.fao.org.

7. Hedge DM. Becoming self-reliant. Hindu survey of Indian agriculture 2004, P45-47.

8. Khaleque MA, Begum D. Area and production of Oilseed crops, 1988-90. In fifteen years of oilseed research and development in Bangladesh. AST/CIDA 28:190 1991.

9. Kiresur VR, Rumana Rao SV, Hedge DM. Improved Technologies on Oilseeds Production - An Assessment of their Economic potentials in India. Agric. Eco. Res. Rev 2001;14:95-108.

10. Sagar RL, Ganesh Chandra. Front line demonstration on Sesame in West Bengal. Agricultural Extension Review 2004;10:7-10.

11. Samui SK, Mitra S, Roy DK, Mandel AK, Saha D. Evaluation of front line demonstration on groundnut, J Indian Soc. Sostal Agric. Res 2000;18(2):180-183.

12. Tunde-Akintunde TY, Akintunde BO. Some physical properties of sesame seed. Biosyst Engin 2004;88:127129. 